\title{
FORAGERS, FARMERS AND FISHERS: RESPONSES TO ENVIRONMENTAL PERTURBATION ${ }^{1}$
}

\author{
Monica Minnegal and Peter D. Dwyer \\ The University of Melbourne
}

\section{Introduction}

The role of environmental perturbation in shaping human society and culture has received increasing attention of late, attention that reflects a growing sense that global environmental changes currently underway will have unpredictable and potentially disastrous consequences in local contexts (e.g. Beck 1992; Caplan 2000; Grove and Chappell 2000; Haberle and Chepstow Lusty 2000; Hester and Harrison 2002; Hoffman and Oliver-Smith 2002; Kirsch 2001; Oliver-Smith and Hoffman 1999; Rees 2003; Torrence and Grattan 2002). Here, we take the word 'environment' to refer to 'that which surrounds' and consider that, for analytical purposes, both 'environments' and 'perturbations' may embrace referents other than the physical and biological. Earthquakes, volcanic eruptions, drought, and global warming may all disrupt people's relations with local environments but, so too, may the intrusion of external political and economic systems. The consequences of the latter perturbations have been the particular concern of political ecology which, in different ways, analyses articulations between nature, society and history to identify relations of power and practice and draw connections with the sustainability of either or both local life-ways and local environments (Biersack 1999; Brosius 1999; Escobar 1999; Peet and Watts 2004; Robbins 2004; Vayda and Walters 1999; Walker 2005). Recent studies have tended to focus on particular cases of perturbation and response, seeking evidence of resilience or vulnerability, of continuity or change in the affected society. Details of the perturbation itself, or the extent to which people may be either directly implicated in the events that befall them, or positioned by broad-scale political and economic factors to respond as they do, are often central to the discussion.

In this article we take an explicitly anthropological approach to a study of human responses to environmental perturbation. We use a comparative model that recognizes and prioritizes the role of prevailing expressions of ethos and sociality in conditioning responses to perturbation and which, thus, takes variation in those expressions as focal to analysis. In doing so we are aligned with the humanistic and environmentalist agendas of political ecology while striving to develop a more generic understanding of processes that shape human action in, as well as on, the worlds that people experience. With reference to ethos and sociality, those processes, we assert, are likely to have similar conditioning or constraining effects irrespective of whether the source of perturbation is judged to arise from external physical or external politico-economic causes. To an important extent this is because the ways in which people respond to events that befall them are, in the first instance, shaped by their own understandings of the causes of those events and, hence, by ways in which they themselves assign or accept blame and responsibility. We seek to direct attention to the importance of these aspects of response to perturbation.

Our analysis is predicated on recognition of the recursiveness of the relationship between people and environment. The ways people respond to perturbations are conditioned by the ways they understand and organize relationships with the environment and with other people, but perturbations may also challenge such understandings and stimulate changes in practice. First, then, we ask how sociality and ethos may influence short term responses to perturbation. Our data here come from two Papua New Guinean societies, Kubo and Bedamuni, and the perturbation was an extended drought during 1997 (Minnegal and Dwyer 2000a). Secondly, we ask how perturbation may, in the longer term, influence the emergence of new forms of sociality and ethos. Our data come from two communities of commercial fishers, seiners who target whiting and flathead and scallopers, at Lakes Entrance in Victoria, Australia (Dwyer et al. 2003; Minnegal et al. 2003), and the perturbations were past 'collapses' in those fisheries. Our analyses of these short and longer term responses are situated within a descriptive and comparative frame that concerns dimensions of social complexity. Finally, we ask how people's understandings of the cause of perturbations may influence their responses. Here, we

1. Our research has been supported by The University of Queensland and the University of Melbourne, and, in part, by grants from the Papua New Guinea Biological Foundation and the Australian Research Council. We thank Simone Blair, Tanya King, Kay Milton and referees for discussion and comments, and the many Kubo, Bedamuni, and Lakes Entrance people who have tolerated our intrusions into their lives. We acknowledge also the many ways in which the late Mary Douglas has both influenced, and stimulated, our anthropological imaginings. 
draw on data from both Papua New Guinea and Lakes Entrance. ${ }^{2}$

We shall argue that different communities of people may, in the short-term, exhibit different responses to essentially the same perturbation and, in the longer-term, develop different strategies of accommodation to potential perturbations. We use 'community' to refer to sets of actors who share a substantive interest in common but are not necessarily bounded by membership or place. Our particular interest is with the social relations which inhere in and sustain community (e.g. Amit 2002). There is no sense, however, in which we seek to map the two fisheries onto the two New Guinean societies or vice versa. Rather, while the latter guide our analyses of the former, the conjunction of the two studies adds to an understanding of both. We seek to contribute to a comparative understanding of ways in which people cope, or fail to cope, with environmental perturbation irrespective of the source or nature of that perturbation (cf. Caplan 2000; De Garine and Harrison 1988; Gezon 1999; Hoffman 1999a; Hewitt 1983; McCabe 2002; Meltzoff et al. 2005; Milton 1996; Thompson et al. 1990; Trawick 2002).

\section{Social Complexity: A Comparative Frame}

Elsewhere we have argued that the complexity of social systems may be represented in terms of two broad dimensions that, borrowing from Langer (1967), we term the 'involvement of parts' and the 'individuation of form' (Fig. 1A; Minnegal and Dwyer 1998). Each dimension is itself multidimensional. The former may be represented by the number and kinds of parts that comprise a system (i.e. differentiation) together with differences in the intensity of connections that link those parts (i.e. integration). In human systems the relative involvement of parts reflects characteristics such as the degree of role specialization or status differentiation, and processes (e.g. conventions of leadership and dispute resolution) that facilitate their maintenance and reproduction. These sorts of characteristics are often taken to be indicative of lesser or greater degrees of inequality or hierarchy. The individuation of form of a system may be represented by the degree to which it is demarcated from that which surrounds it; in short, the degree to which it is closed or bounded. Thus, in human systems, it reflects characteristics such as relative restriction of membership or tenurial arrangements, which are themselves aspects of integration, and, particularly, implicit or explicit evaluations that promote attitudes of inclusion or exclusion with respect to others.

Our identification of two dimensions of social complexity has some similarities to the gridgroup typology of social environments proposed by Douglas and subsequently modified and extended by Thompson et al. in an exploration of the "ways of life" available to individuals (Douglas 1970, 1982:183-254; Thompson et al. 1990; see also Milton 1996: 88-92). Douglas defined grid in terms of "rules that relate one person to others on an ego-centric basis" and group as "the experience of a bounded social unit" (1970: viii). She considered that the strong end of grid was characterized by segregation (or differentiation) in "places and times" and by the "physical signs of discriminated rank;" at the weak end "substantive signs of ascribed status are scrapped" (1982:192). The group axis, in her typology, reflected the degree to which a group of interacting individuals "is defined in terms of the claims it makes over its constituent members, the boundary it draws around them, the rights it confers on them to use its name and other protections, and the levies and constraints it applies" (1982:193). These axes, therefore, are similar to the dimensions we label 'involvement of parts' (grid) and 'individuation of form' (group).

Our model, however, differs strongly from those of Douglas and Thompson et al. in its explicit focus on social systems per se rather than on social environments (Douglas) or the orientations of individuals within social environments (Thompson et al.). Partly as an outcome of these different foci we do not always concur with those earlier writers either with respect to assigning particular features of social systems to particular axes or with respect to the specific meanings given to a number of key terms. Thus, for example, where Thompson et al. use the terms 'hierarchy' and 'egalitarianism' to characterize positions in two-dimensional space we use them only with reference to relative locations on a single dimension, that of 'involvement of parts' (or 'grid'). Similarly, where they tend to use the word 'autonomy' to refer to an 'absolute' state we prefer to problematize the concept, distinguishing it from 'individualism' and allowing, at the least, degrees of 'autonomy'. Though we have been influenced by, and shall draw on, their understandings this is not the place to catalogue all our differences. Of more significance is the fact that the schemas developed by Langer, Douglas and

2. In this paper we draw on research among Kubo spanning the years 1986 to 1999, among Bedamuni spanning the years 1995 to 1999, and among Victorian fishers spanning the years from 2000 to 2004. 

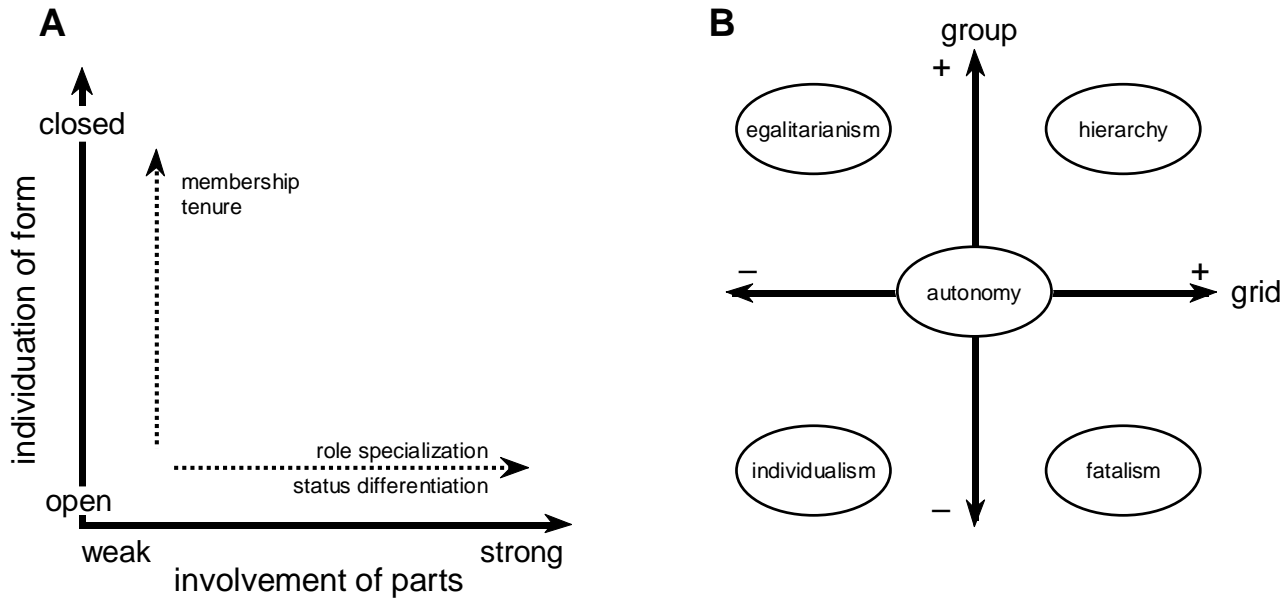

Fig. 1. A. Dimensions of social complexity. On the horizontal axis complexity increases as, for example, role specialization or status differentiation increases. On the vertical axis complexity increases as, for example, membership within a group or ownership and access rights to land are increasingly closed or restricted. B. Ways of life mapped on axes of 'group' and 'grid' (after Thompson et al.1990; see text for further explanation).

Thompson et al. were all explicitly concerned, as we are, with issues of change. Three particular matters, however, merit attention.

First, where we, as does Douglas (1982:205), allow a universe of continuous variation, Thompson et al. insist that their model yields "five and only five ways of life" which they label "hierarchy, egalitarianism, fatalism, individualism, and autonomy" (1990:3). While accepting that many points within the universe of our model may be unstable we are unwilling to concede that forces of change drive systems, or ways of life accessible to individuals, to the corners (and the center) of the diagrammatic representation that Thompson et al. provide (see Fig. 1B).

Secondly, Thompson et al. order both axes of their diagram from negative to positive whereas we order analogous axes from weak to strong and from open to closed or, if quantification were possible, from zero to infinity. We do not accept that features characterizing either grid or group in their terminology, or involvement and individuation in ours, may be assigned negative values. For example, an ethos of egalitarianism or prescriptions on group membership could be absent and, hence, assigned a value of zero but they cannot take values less than zero.

Our third point of at least implicit disagreement with Thompson et al. is methodological and concerns scale effects. Though they, like us, do not quantify the axes of their diagrammatic schema the implication in their case is that points in grid-group space take fixed values such that all life-ways may be simultaneously compared. By contrast we consider that the primary utility of our schema is as a heuristic device for comparing the relative location of systems that, from the outset, are judged to be commensurate. With specific reference to the present article we might (and do) compare the relative positions of the two Papua New Guinea societies or of the two fishing communities but would be on dangerous ground if we attempted to locate all four groups simultaneously within the two dimensional universe represented by the axes of involvement and individuation. ${ }^{3}$

3. The problem arising here is common in studies of communities and ecosystems in scientific biology. For example, a favored causal explanation of the observation that the number of species varies between places - with, for example, latitude or altitude - is that higher diversity is associated with 'intermediate' levels of disturbance (e.g. Connell 1978; Whitmore 1998). But measures of disturbance, and diagnoses of intermediate disturbance, that may correlate with the diversity of trees in different forests, or the diversity of invertebrates in different kinds of 


\section{Papua New Guinea: Kubo and Bedamuni}

Kubo and Bedamuni are neighboring groups within the Strickland-Bosavi complex of languages (e.g. Dwyer et al. 1993; Knauft 1985; Shaw 1986). They occupy similar environments (lowland and foothill rainforest), are culturally related and utilize similar technology and resources. But Kubo are hunter-horticulturalists, whose subsistence base combines a major emphasis on immediate-return resources with shifting agriculture. They are the 'foragers' of our title, switching readily between reliance on wild and domesticated staples. Bedamuni, in contrast, are 'farmers' who, while they do hunt, rely primarily on delayed-return resources - particularly from gardens - for subsistence.

These different orientations are reflected in the fact that both the intensity of land use and social complexity are greater among Bedamuni than among Kubo (Minnegal and Dwyer 1998, 2001). About 500 people speak the Kubo language. Most live between 80 and $200 \mathrm{~m}$ ASL and average population density is 0.4 people per $\mathrm{km}^{2}$. About 5000 people speak the Bedamuni language. Most live between 200 and $400 \mathrm{~m}$ ASL and average population density is 7 people per $\mathrm{km}^{2}$.

Tenure arrangements among Kubo emphasize the use individuals make of land and make few operational distinctions on the bases of genealogical connection or gender while, among Bedamuni, genealogical connection to clan land is important and the use rights of women are contingent upon their status as daughters or wives to male owners (Dwyer and Minnegal 1999). Kubo are a more mobile people than Bedamuni, changing places of residence more often, associating as residential groups of mixed clan membership, and sustaining these relatively fluid arrangements by an ethos of individual (or family) autonomy and sharing. The latter is expressed publicly on a daily basis and is notably more generalized than seen among Bedamuni. Again, among Kubo and in contrast to Bedamuni, neither gender nor age are strongly implicated in differentiating people on axes of status or assigned authority. The former people are likely to respond to intracommunity disputes by one or the other of the affected parties departing to live elsewhere, while among the latter people, where options to live elsewhere are limited, disputes are resolved by relatively formal strategies of negotiation. Finally, Bedamuni have a strong sense of themselves and of their place as Bedamuni, a sense of common identity and centrality that is reinforced by myth (Dwyer and Minnegal 2000). Kubo do not indulge in analogous self-referential judgments. On all these counts, and others, the Kubo socioecological system shows less differentiation, less integration, and less evaluation than does the Bedamuni system. Thus, the latter qualifies as more complex than the former with respect to both the involvement of parts and the individuation of form (Fig. 2).

The drought of 1997-98 was one of the most severe to affect Papua New Guinea in the previous 100 years (Bourke 2000; Allen 1998). By July 1997 it was widespread. In some highland areas critical food shortages were reported where frosts had destroyed the sweet potato crop and, in some lowland areas, garden production was greatly reduced and yields from sago palms were either directly or indirectly affected. By mid-October 1997, both Kubo and Bedamuni had been assessed as having only famine food available, with drinking water in poor condition or limited supply and some children and elderly people at risk (Allen and Bourke 1997). By the end of that year more than a million Papua New Guineans were thought to be "suffering a severe, and to some a life threatening, food shortage" with another 250,000 exposed to critical or severe water shortages (Allen et al. 1998). Like other populations judged to be seriously affected Kubo and Bedamuni were recipients of food aid from late in 1997 to early in 1998.

Available records for 1997 suggest that in both Bedamuni and Kubo territory annual rainfall was reduced to about 50 percent of normal (5-6 m/year) and, in three critically dry months, was only about 10 percent of normal. However, despite occupying similar environments, and exhibiting very similar technological capacities, Bedamuni felt the effects of the drought much more intensely than Kubo (Minnegal and Dwyer 2000a). They experienced the total failure of gardens, greatly reduced availability of sago flour, reduced access to sources of animal protein, a relatively high mortality rate of domestic pigs, general debilitation of the population, some drought-associated deaths and a high

soils, cannot be extrapolated to comparisons that cross-cut these ecosystem categories - that, for example, seek to explain why the number of species of tree in a particular forest is less or more than the number of invertebrates in a particular type of soil. Regimes of disturbance applicable to the two types of system are incommensurate. In a similar way judgments or measures of, for example, status differentiation or constraints on membership within one set of related groups of people may not be readily extrapolated to groups whose social relations are underlain by different epistemological positions. 


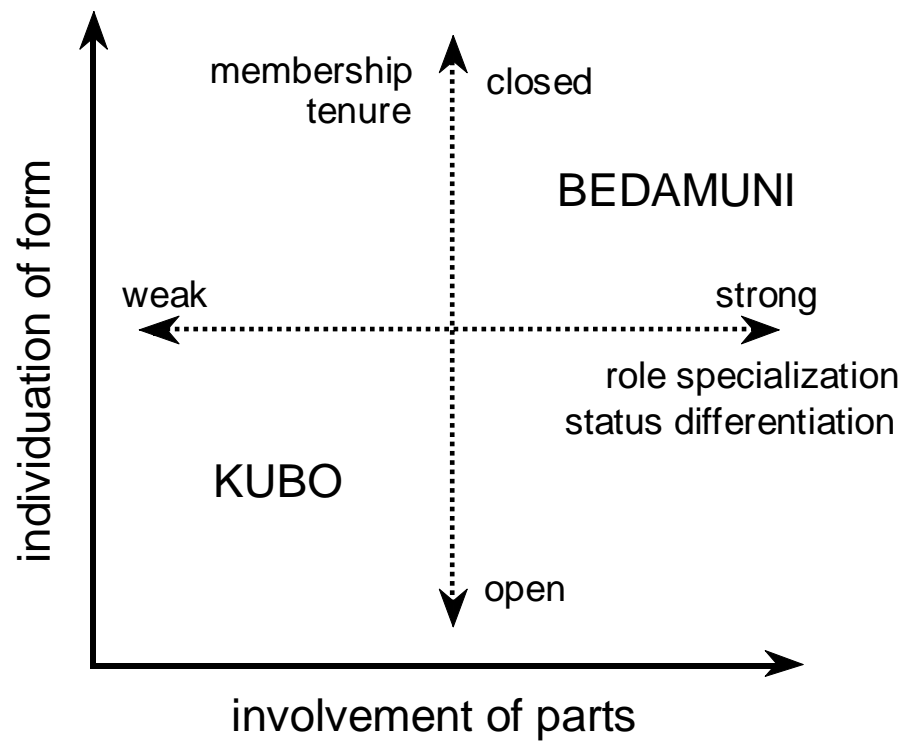

Fig. 2. The relative locations of Kubo and Bedamuni within the universe of social complexity depicted in Figure 1A

level of tension leading to fission of some communities. By contrast, Kubo maintained some productive gardens, though they altered the primary location of these from the levee banks of rivers and large streams to small rises in back swamps and they altered the balance of crops in favor of sweet potato. They were probably never short of sago flour though, because smaller streams carried less water or had dried, processing became more arduous, and they did not experience a reduction in either access to animal protein or the numbers of domestic pigs. While food aid was crucial to Bedamuni survival in late 1997 and early 1998 this was not the case for Kubo who were able to direct much of what they received to sponsoring feasts.

In part, the differential impact of drought on the two populations correlated with interactions between local geographic circumstances (altitude, topography, drainage) and the ways in which people had accommodated modes of subsistence to those circumstances. In the more hilly terrain of Bedamuni territory the location and consequent exposure of ridge-top and upper slope gardens led to collapse of crops during periods of sustained higher temperatures that were associated with runs of days with no rain. Kubo, by contrast, locate most gardens in places where the water table is relatively high and the soil less vulnerable to drying. For these people also, proximity to back swamps contributed to favorable outcomes with respect to access to both sago flour and animal protein. But these differences between the two populations were themselves influenced by choices that people had made within the context of existing constraints. And here, of course, the choices people make - the ways in which they dwell in and build environments (cf. Ingold 2000) - are informed by prevailing expressions of ethos and sociality.

Among both Kubo and Bedamuni there were many residential changes during the course of the drought. It is differences in the nature and the bases of these movements that offer a key to understanding differences in their overall responses to the drought.

Many Bedamuni people relocated as family groups, for at least short periods, from villages on ridge tops to bush houses that were at lower altitudes and near rivers. They did so because these locations provided some protection from debilitating temperatures and to facilitate access to water for drinking and, in the earlier months of the drought, processing sago. These movements, however, were local. They were relocations within the normal subsistence domains of those who participated. They did not greatly enhance opportunities for people to gain access to food though they may have made it easier to refrain from sharing what they had. Other movements by Bedamuni were on a larger scale 
with respect to the number of people involved. They were responses to intracommunity tension - often preexisting, but exacerbated by, the drought - that led to a segment of the original village departing to establish an independent community elsewhere. But again, these break-away communities were located within former subsistence zones, perhaps as little as a 15 minute walk from their former village. Community fission reduced the frequency and range of day-to-day interactions but probably had little material effect on access to food.

Many Kubo people also relocated during the drought. In contrast to Bedamuni, however, their movements were not constrained by either clan boundaries or the subsistence zones conventionally associated with particular communities. Some moved relatively short distances, to locations where the supply of drinking water was more favorable. But many moved much further, well beyond their usual range, to the vicinity of backswamps where sago resources were least threatened, small gardens continued to be productive and animal foods were accessible. The outcome was that, through the course of the drought, movements by Kubo people led to somewhat larger assemblies of people while movements by Bedamuni people led to some fragmentation of previously existing assemblies. And, further, among the former people the satisfactory outcomes achieved through the drought made it more likely that people who had moved interpreted that relocation as a relatively permanent change of residence.

The differences in drought-related movements of Kubo and Bedamuni were intimately connected to the differing forms of ethos and sociality we described above. Kubo, it seems, pattern their lives around an expectation that availability of resources will be often in flux. They emphasize flexibility and autonomy in both subsistence and residential arrangements, ensuring the former with an ethos of generalized sharing and the latter by recognizing that associations with land are established through use, not given by genealogy. Bedamuni, in contrast, pattern their lives around an expectation of favorable returns on effort put into land. They emphasize commitment and convention in both subsistence and residential arrangements, ensuring security of access to expected returns by insisting that association with land is non-negotiable, requiring conformity to conventional roles and submission to authority.

These distinctive strategies of living in what are similar physical environments may be summarized as risk-averse and risk-prone respectively. In the contexts of prevailing population densities, Kubo forego potential higher returns on effort and emphasize means of ensuring security of supply while Bedamuni strive to maximize returns and emphasize means of ensuring security of tenure to protect those returns. It is these differences between the two language groups - differences that are traceable to expressions of ethos and sociality - that were primary in shaping their responses to the drought of 1997-98.

Thus, the impacts of the drought upon Kubo and Bedamuni were not merely outcomes of different environmental circumstances, population densities or subsistence regimes. They arose within the context of prevailing social forms and of understandings people held with respect to relationships with both environment and other people. To the extent that Bedamuni understood those relationships as both ensuring favorable returns on effort and hedged with constraints, so we may appreciate why a major environmental perturbation threatened their livelihood more than it threatened the livelihood of Kubo. Several authors (e.g. Oliver-Smith 1999:87; Zaman 1999:208) have directed attention to likely connections between vulnerability and social formation. Sheets (1999), in an archaeological analysis of long-term responses to volcanic eruptions in Middle America, concluded that vulnerability was greater in more complex (i.e. ranked and stratified) than in less complex (i.e. egalitarian) societies. In this comparative study vulnerability was judged to be greatest where the time lag to recolonizing a devastated area was greatest and where recolonization was likely to be by different people with different socio-economic systems. In the less complex societies discussed by Sheets, low population density, an ethos of mobility and lack of commitment to a specialized mode of subsistence facilitated relatively early return to abandoned lands by people whose way of life was like that of the original inhabitants. Thus, Sheets' conclusions with respect to Middle America parallel ours with respect to the two Papua New Guinean societies.

\section{Fishing Communities at Lakes Entrance}

Lakes Entrance is a coastal town, $275 \mathrm{~km}$ east of Melbourne, Victoria, with a resident population, in 2003, of about 5000 people. It is at the eastern end of $400 \mathrm{~km}^{2}$ of interconnected lakes which are used by both recreational and small-scale commercial fishers. Fishing and tourism are major industries and, at the peak of the tourist season, the population may swell to 30,000 or more. The two 
Lakes Entrance fishing communities discussed in this paper are, in the first instance, defined by the fact that participants in each utilize a particular and distinctive fishing technique in pursuit of their livelihood. Both communities fish ocean waters. One comprises seiners who use a specialized trawling technique to target, particularly, school whiting (Sillago sp.) and species of flathead (Platycephalus spp.), and the other scallopers who dredge soft bottomed substrates to target species of scallop (Pecten and Chlamys spp.).

In this section we first provide brief accounts of the history of each of these fisheries at Lakes Entrance and report the distinctive perturbations that they experienced. We then describe current social characteristics of the communities that have developed since those earlier perturbations.

\section{(a) A Brief History of the Danish Seine Fishery}

Within Australia, the Danish seine fishery commenced in New South Wales in 1933. Danish seine fishing gear is light relative to that used by larger otter-board trawlers. The crew pays out about $1200 \mathrm{~m}$ of rope, attaches the wings and cod end of the net and, paying out another $1200 \mathrm{~m}$ of rope, returns to its starting place; the ropes are arranged to form either a triangle or diamond shape. The net is now winched in as the boat steams slowly ahead. Mud or sand raised by the tightening ropes herd fish toward and into the net. The vessels are relatively small and can operate in inshore waters that are not usually fished by larger trawlers. By the mid-1940s, when many larger trawlers had been commissioned for war service by the Australian Navy, Danish seine vessels dominated the coastal fishing fleet of New South Wales and there was a shift from owner-operated boats to increasing investment by entrepreneurial businessmen without previous experience in the industry (Mead 2002:237). ${ }^{4}$ By the late 1940s returns from Danish seine fishing had declined, new grounds were discovered off Lakes Entrance in Victoria, and, "in the virtual absence of management restrictions" (Caton 2002:109), much of the fleet moved south. Most who did so were owner-operators though a few, who were themselves fishermen, ran several boats. By 1949 about 65 Danish seiners were operating out from Lakes Entrance. The local boom, however, was short-lived. One participant described what happened as follows:

Within six years there was only eight trawlers left. They'd gone bankrupt because they'd caught so many fish and so flooded the markets that all they got back was a bill for their fish. They all went broke. This carried on till roughly 1954 when a chap by the name of Bill Jevons, the main instigator and myself, got to work and we formed an organization called the Victorian Fishermen's Co-operative. The intention was stabilizing the Danish seine industry and getting a better price for our product by distributing it to new interstate markets. It was quite successful. We started putting a quota on the amount of fish brought into Lakes .... (Frank Newman, in Lee and Ellis 2002:43).

It was, indeed, quite successful. The Victorian Fishermen's Cooperative grew to become the Lakes Entrance Fishermen's Cooperative Society Limited (LEFCOL) which now provides services to all fisheries at Lakes Entrance. By the late 1980s the entire southeast Australia Danish seine fleet had contracted to about 30 boats (Tilzey and Rowling 2001:362) and, progressively, relocated to Lakes Entrance. From 2000 to 2004 all but three of the fleet of 20 Danish seiners were based at the port of Lakes Entrance. Since the early 1990s, after the introduction of Individual Transferable Quota (ITQ) management, most owners in the Lakes Entrance fleet have pooled their quota and operate under the

4. Mead (2002) provides an interpretative reconstruction of late $19^{\text {th }}$ and early $20^{\text {th }}$ century whaling days at Twofold Bay, New South Wales. His account is based on extensive interviews conducted in the late 1940s and 1950s with participants in the whaling industry. Towards the close of the book he constructs a conversation between two retired whalers. The time is February 1945, before the end of World War II. The men look out over the bay, to the wharves, and reflect on the fact that, as long as the war lasts, business will be good for local shipyards but not for fishermen who had been working from the larger trawlers. "Most of the trawlers were taken from here for supply ships in New Guinea and the islands. It's a pity. With meat rationing on and the big steam trawlers doing mine-sweeping, those working seine trawlers are earning big money, though it's the same story - a few opportunists and racketeers getting most of it. ... One of those trawlers over there is owned by some bookmaker who's never been to sea in his life. He sits on his backside ashore, making a fortune by black marketing the fish these men catch. ... Another one of those ships is owned by a builder, another by a publican, and two or three belong to Sydney fish agents - anyone except the fishermen who do the work and catch the fish" (2002:237). 
auspices of the Lakes Entrance Danish Seine Unit Trust (Connor and Alden 2001:390; Tilzey and Rowling 2001:363). Again, since 1991, fishing effort by Danish seiners has remained relatively stable with fluctuations in the catch of primary target species (school whiting and species of flathead) variously attributed, at least by fishers, to prey-switching consequent upon market forces, weather conditions and reduced accessibility caused by an increase in algal growth on some fishing grounds (Caton and McLouglin 2000:122-28).

No substantive concerns about, at least, school whiting stock have been expressed by either scientists or managers though flathead, which are also taken by larger otter-board trawlers, are judged to be "fully fished" (Caton 2002:117-18). Bennett et al. (2002:193) assert that Danish seining is a low impact trawl fishery that is "sustainable as long as the effort is not too dramatically increased by more boats.” At Lakes Entrance, since the early to mid-1990s, the Danish seine fleet has been remarkably stable relative to those of other fisheries.

\section{(b) A Brief History of the Scallop Fishery}

In Victorian waters, a scallop fishery, using bottom dredges, first developed in Port Phillip Bay in 1963 (Seafood Industry Victoria 2003). Competition from an influx of Tasmanian fishers, reduction in the abundance of scallops, and progressive introduction of size limits and access restrictions, encouraged fishers to seek alternative beds. In 1969 rich beds were found off Lakes Entrance and, through the 1970s and early 1980s, these, together with newly discovered beds in Commonwealth waters north of Tasmania, led to a huge increase in the number of boats targeting scallops. At Lakes Entrance, until the late 1970s, senior figures within the fishery regulated the catch per boat to ensure high returns from the market, imposed a 'tax' to cover costs of fleet managers, maintained good relations with processors, and sought to limit the number of participants in the fishery. Their rule was, perhaps, characterized by a mix of favoritism and despotism but, for many fishers, that period is remembered as a time of excitement, easy money and careful, market-informed use of resources.

During the late 1970s, as a direct consequence of legal and government intervention, the scallop fishery was opened to all-comers and earlier, internal regulatory practices broke down. At this time a tax-minimization scheme operating under the name Allied Fisheries built and sold about 60 boats to syndicates of investors who were often doctors, lawyers and business men with no previous connection with fishing. Many other fishers fitted scallop dredges to their boats. At Lakes Entrance alone the size of the scallop fleet grew to more than 80 boats with most operators acting independently and without constraint. Fishing effort increased dramatically, stock was progressively depleted and recruitment jeopardized (Bennett et al. 2002:83,87; Caton 2002:208; Caton and McLouglin 2000:202-03). Exceptionally high catches were achieved for five or six years but by 1985 the fishery had collapsed, Allied Fisheries was bankrupt, and the laissez faire management regime of earlier years was progressively replaced by an increasingly stringent mix of input (e.g. seasonal entry, closures and licensing constraints) and output (e.g. size and bag limits) controls.

The scallop fishery has never returned to its former glory. Since the mid-1980s fleet size has progressively declined, closures have occurred more often and for longer periods, processing businesses have failed and most of the remaining participants - those who did not abandon fishing have survived by shifting into other fisheries when scallops are few or unavailable. In some cases, as is now common among lobster fishers in Tasmania, scalloping has become a secondary fishery that is accessed only in years when State or Commonwealth managers declare beds to be open (Phillips et al. 2002; Tasmanian DPIWE 2003). At Lakes Entrance, fishers may shift between targeting scallop and, for example, squid, prawn or shark. While there is an association of scallop fishers, its role is rather different from that of the Danish Seine Unit Trust. The Victorian Ocean Scallop Association, based at Lakes Entrance, acts to coordinate political lobbying, sponsor legal appeals against management decisions and exchange information about potential crew, processing opportunities and the market. Its dominant focus is with a possible future where scallops will be again abundant or managers will be more generous to, and understanding of, the needs of fishers. The headquarters of the Association is a venue where people reminisce about earlier days, gather in anticipation when a boat offloads scallops at the start of the season or after returning from a management-sponsored survey, or contemplate a secure future in which they hold property rights over artificially re-seeded wild beds of scallops.

Relative to the Danish seine fishery the scallop fishery has, for twenty years, been characterized by booms and busts in the availability of harvestable stock to fishers and by insufficient data to monitor resource trends or implement satisfactory management (Caton 2002: 209). 


\section{The Fishing Communities Today: Seiners and Scallopers}

At Lakes Entrance the current Danish seine and scallop fisheries have developed in the aftermath of major perturbations that occurred in the 1950s and 1980s respectively. In the first case, the perturbation is interpreted by fishers to have been a consequence of flooding the market and reducing prices to below the threshold of economic viability; fishers deny that the survival of stock was jeopardized and their assertions have not been contradicted by scientists or managers. In the second case, the perturbation was a consequence of legal decisions and management failures that created conditions conducive to over-fishing and eventual collapse of stock. From the perspective of each community of fishers, and irrespective of the extent to which they acknowledge or deny some responsibility for what happened, the collapse of prices and the collapse of stock may be understood as environmental perturbations which, like the 1997 drought to Papua New Guineans, threatened livelihood through their impacts on the value or quantity of crucial resources. ${ }^{5}$

Our interest here is with the present-day form of the two communities of fishers which have developed since, and in response to, the perturbations described above. In both fisheries the preconditions for collapse were perceptions of great resource abundance, very rapid expansion of the fleet and minimal intrinsic or extrinsic constraints on fishing effort or catch. Scientists were optimistic about stock, government managers were enjoined to promote new industries, and fishers were enthusiastic about the promise of secure and substantial wealth. But despite these commonalities of originating conditions the communities which have emerged post-collapse are very different. At Lakes Entrance, that difference is most clearly expressed through expressions of social relations that now characterize these two communities of fishers - the seiners and the scallopers.

Through the four years of our research, most owners and skippers of Danish seine trawlers have been long-term residents of the town of Lakes Entrance. The seiner community is, thus, strongly locality based. Through that period, membership has been relatively permanent even to the extent that deckhands are usually locally recruited and, though they may switch between boats or find some skippers difficult to work with, relatively long-term employees. Further, most boats in the fleet are skippered by owners or sons of owners and most are dedicated seiners. ${ }^{6}$ One outcome of these characteristics, and the practice of seiners mooring their boats in the same area of the port, is a high frequency of face-to-face interaction on the wharves by owners and crew of different boats. This facilitates the exchange of information which is so important to fishers (e.g. Andersen 1972; Baelde 2001:413; Stiles 1972), renders those exchanges visible to others and provides opportunities to assess the worth of those others with respect to their knowledge and trustworthiness. But among seiners social interaction reaches beyond the specifics of fishing. A significant group of owner-skippers went to school together and entered fishing at about the same time. They socialize often outside the context of work and, as relatively young men whose fathers had little or no history in fishing, are neither bound by nostalgia for the past nor beholden to the understandings of local pioneers in the Danish seine fishery.

The distribution of boat ownership within the Lakes Entrance Danish seine fleet constitutes a relatively level playing field. In two cases - a father and son and two brothers - members of one family own separate boats. All other boats are owned by members of different families. This, together with the social characteristics mentioned above, facilitates the remarkable degree of cooperation displayed by these fishers. At the start of each fishing year, members of the 'pool' hand over their Commonwealth allocated quota to the Lakes Entrance Fishermen's Cooperative. It is subsequently returned to them on an 'as needed' basis such that the excess of those who do not fill their own quota is available for lease to members who, for one reason or another, may have fished more often. Further, at the start of each fishing week the Co-op advises fishers of the amount that the market will take at a satisfactory price and this is shared equally by those who fish in that week. The outcomes are that members of the seine

5. Insider and outsider understandings of the causes of environmental perturbations may or may not be congruent but, irrespective of the understandings of outsiders (e.g. scientists, Government agencies), both short and long term responses to those perturbations, and the ways in which they are remembered, will be framed by the understandings of those who experienced them directly (e.g. Button 1999; Dwyer and Minnegal 2000; Laksono 1988; Paine 2002; Quesada 2001; Skinner 2000).

6. Between February and June 2002 only one of 17 Danish seiners switched gear and participated in a different fishery. For seven weeks this boat operated as an inshore prawn trawler. In the winter of 2003, four of the Danish seiners spent a few months targeting scallops. 


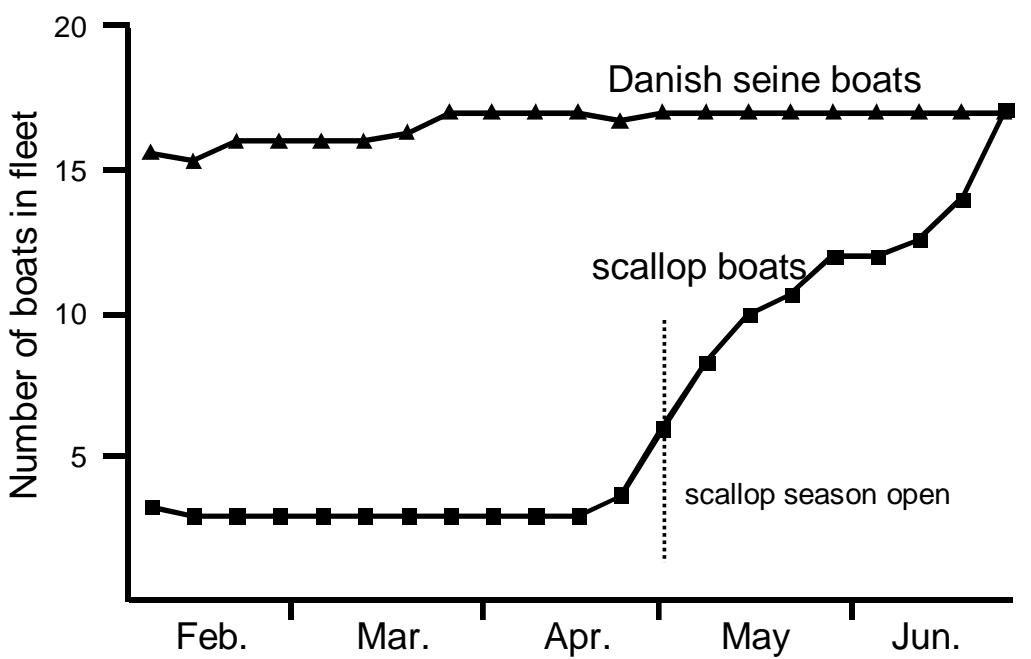

Fig. 3. Comparison of Lakes Entrance Danish seine and scallop fleets: February to June 2002. The number of boats rigged as seiners and scallopers respectively are shown for each week commencing on February $3^{\text {rd }}$; values are averages based on daily surveys. All boats in the seine fleet were based at Lakes Entrance. Nine of the boats in the scallop fleet arrived early in the season - May $1^{\text {st }}$ onwards from other Victorian ports. Through this period six local boats switched from inshore trawl gear to scallop gear.

pool are not competing for differential access to the market and, to some extent, buffer each others financial returns. Indeed, they do not directly negotiate with buyers but, rather, have assigned this responsibility to appointed agents at the Co-op. Those outside the pool must compete as individuals against the collective, and are often excluded from access to better prices. It is not surprising, then, that most seiners at Lakes Entrance have opted to join the pool. But entry is at the discretion of existing members.

Seiners, then, are essentially an egalitarian community, willing to exchange information and encouraged, on the basis of advice from the Co-op, to fish only when prices are favorable and the weather is satisfactory. They tend to fish in synchrony - on the same run of days - though individuals show different preferences with respect to distance traveled and, as a corollary, some return to port several times over a three to four day run of fishing and others only at the end of that period.

More than half the owners of scallop boats that fish from Lakes Entrance are not residents of the town and about half the boats in the fishery are present at Lakes Entrance only when suitable scallop beds have been declared open by managers. Many of the skippers and deckhands who work on these boats are temporary residents of the town and, in the case of deckhands, often itinerant. And, further, relatively few of the boats that are usually based at Lakes Entrance are dedicated scallopers and their skippers are seldom either the owner or kin to the owner. In all these ways both the scallop fleet and the community of scallop fishers is ephemeral (Fig. 3). Many boats are often absent from Lakes Entrance or rigged for other targets. And, similarly, many owners and crew are often absent or have other priorities. Even in season, bag limits may mean that an owner's permitted catch can be achieved in a few days of fishing each month and that for much of the rest of the time there is little impetus for crew to hang around the wharves or even to remain in town. Boats that arrive from elsewhere when beds are declared open must moor in whatever berths are not already claimed, so the fleet is dispersed through the port. Face-to-face interaction at wharves, then, and social interaction outside the context of work, is much more limited among scallopers than seiners. What discussions do occur, often via the comparatively anonymous medium of the telephone, tend to concern management decisions, survey results and marketing opportunities rather than fishing plans. The ephemeral character of the community means that differences between scallopers are measured in terms of their history in the 
fishery rather than current performance. Some current owners were themselves significant actors during the earlier phase of expansion and collapse of the fishery. As senior figures in the industry, the stories they tell encourage nostalgia for a vanished past and hope for a secure future. Seniors who speak with authority characterize the scallop fishery in a way that is not apparent in the Danish seine fishery.

The distribution of boat ownership within the scallop fleet is less uniform than seen in the seine fleet. This is reflected directly in the fact that some scallop fishers own as many as five boats and in perceptions of disparity that arise because many owners are not themselves fishers and some are processors who can both influence the market and write off fishing losses against tax in ways that others cannot. Again, monthly catch limits per fishing permit set by State and Commonwealth managers are usually such that an owner operating with a single permit cannot derive an income sufficient to support a family from fishing for scallops only. Each year, owners make judgments as to whether they will or will not participate in the fishery. Those who do not participate make their quota available for lease, encouraging intense competition for access to that quota among other fishers. Thus, inequalities are also evident in disparities in the number of permits tied to each boat and in the outcomes of negotiating access to quota. In addition, scallopers differ in their ties to processors and thus have differential access to markets. Because some owners are themselves processors, or have strong ties to processors, perceptions of conflict of interests arise that cause some fishers to suspect the motives of others and disrupt the always delicate cohesion of the community as a whole.

All these factors, together with on-going and often private negotiations with processors who buy the catch at point of landing, promote competition among scallop fishers. There is simply nothing akin to the forms of cooperation seen among seiners. Nor, given the social relations that structure the scallop community, would such cooperation, reaching as it does to financial matters, be possible. Both the distribution and temporal patterning of fishing effort is much more variable than among seiners. Indeed, to the extent that fishing effort is synchronized across the fleet this is largely a result of constraints imposed by processors and not, as seen with the seine fleet, an outcome of decisions made within the community of fishers.

It is clear that social characteristics of the current seiner and scalloper communities at Lakes Entrance are very different. Reproduction of the former is grounded in far-reaching cooperative relations and a clearly defined, restricted membership while reproduction of the latter is grounded in sustaining access to diverse modes of production and both spatially and temporally fluid membership. Seiners also have a greater sense of proprietorship with respect to targeted resources, a sense of control over access to resources that is reinforced by the fact that their combined catch, especially of school whiting, is considerably less than the allocated total allowable catch (Caton 2002:50-51,55). Among scallopers, by contrast, the perception is of stringent and unfair management-imposed limits on allowable catch that deny any sense of control by the fishers themselves. These different perceptions are reflected in organizational arrangements within the two communities, with the cooperative system established by seiners producing a community that is less stratified than the scalloper community in terms of both access to the means of production and income. The Danish seine community thus appears as more cohesive and egalitarian than the scalloper community and the latter appears as more ephemeral and competitive than the former.

This interpretation is, in fact, reinforced by understandings of the fishermen themselves. Some men move back and forth between the two communities. They may even do so within the course of a year, easily adopting the prevailing ethos and conventions of the community with which they are currently associated. One such man, commenting on the Danish Seine Unit Trust - the 'pool' as it is known to most fishers - said that "the pool shouldn't work but it does because those in it are too lazy to manage things for themselves, they don't want to bother with markets and paperwork, just want to go out and fish." He added that even the board members usually preferred "not to know" when difficult decisions had to be made. And, talking of a venture that had been suggested by some scallopers, he complained that it was “still talk, but nothing happening. That's because some of the bigger ones don't want anything to do with any of the others. They're not willing to cooperate." In his comments, this fisherman was directing attention to the inclination of seiners to allow the group as a whole - the 'Trust' - to handle interactions with the world of markets and management, while not identifying any one individual as having responsibility for associated decisions, in contrast to the tendency among scallopers for particular individuals to claim for themselves the right to act on behalf of the community, claims that are strongly contested by other potential spokesmen. In terms of the model we have proposed, the differences between the two fishing communities may be summarized by noting the 


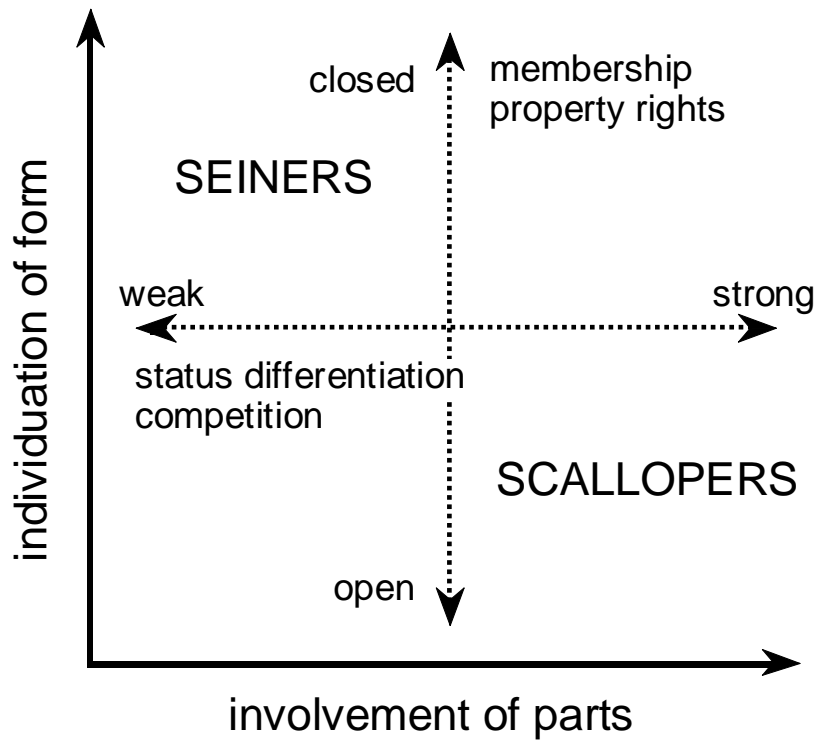

Fig. 4. The relative locations of the seiner and scalloper communities within the universe of social complexity depicted in Figure 1A.

greater 'individuation of form' of seiners relative to scallopers and the greater 'involvement of parts' of scallopers relative to seiners (Fig. 4).

\section{Synthesis: Papua New Guinea and Lakes Entrance}

The very different sociality and ethos of seiner and scalloper communities at Lakes Entrance cannot be understood simply in terms of characteristics of the fisheries in which they are engaged. It is true, of course, that for at least the past two decades the availability of fish to seiners has been more stable than the availability of shellfish to scallopers. But this difference is itself partly a function of the way the two communities have organized membership and structured internal relations. Nor can the difference between the two communities be attributed to the fact that it is nearly 50 years since the collapse of the Danish seine fishery and only 20 years since the collapse of the scallop fishery. The immediate response to collapse by seiners was to move toward, and progressively consolidate, a fishery based in cooperation. Nothing similar has eventuated among scallopers.

Given that the preconditions to collapse were similar in both fisheries we interpret the present form of the communities as reflecting different trajectories of change since those events and, at least partly, in response to them. For two reasons it is therefore of interest to compare characteristics of the fishing communities with those of the Papua New Guinean societies discussed earlier. First, the distinctive expressions of social and ecological relations among the latter were strongly implicated in their different responses to the same environmental perturbation and some characteristics of Bedamuni appeared indicative of potential vulnerability to a major perturbation. Secondly, to the extent that some characteristics of the fishing communities are analogous to those of the Papua New Guinean societies so it might be argued that patterns seen in the latter societies are themselves outcomes of response to earlier perturbations.

The two fishing communities each exhibit some major characteristics that have parallels among Kubo and Bedamuni. These characteristics may be best appreciated by reference to our general account of social complexity (Figs. 1, 2 and 4). We judge seiners to be analogous to Kubo in exhibiting weak 'involvement of parts' but analogous to Bedamuni in exhibiting high 'individuation of form'. Thus, on the one hand, the seiner and Kubo communities show little internal status differentiation and are more cooperative than competitive and, on the other, both the seiner and Bedamuni communities are characterized by restricted membership and group cohesion. By contrast, we judge scallopers to be analogous to Kubo in exhibiting low 'individuation of form' but analogous to Bedamuni in exhibiting 
strong 'involvement of parts.' Thus, on the one hand, both the scalloper and Kubo communities are characterized by loose membership and relatively little group cohesion and, on the other, both the scalloper and Bedamuni communities are characterized by some internal status differentiation and are more competitive than cooperative. While stressing that our comparisons are intended to highlight relative, rather than absolute, differences and similarities, it is apparent that salient characteristics of the fishing communities cross-cut those of the Papua New Guinean communities. It is important, however, to also explore the ecological implications of these structural similarities.

We have described Kubo as showing risk-averse socioecological characteristics that prioritize security of supply over security of tenure and are attuned to an environment in which the availability of resources commonly goes through phases of boom and of bust. Indeed, among these people the initiation of young men reinforced an expectation that access to resources would not be always easy by exposing them over a period of several days to consecutive phases in which they were obliged to do without water, food, tobacco or sleep and, over a period of several years, to do without certain desired foods. We have described Bedamuni as showing risk-prone socioecological characteristics that prioritize security of tenure over security of supply and are attuned to an agricultural system in which, to the extent that people conform to conventional tenurial arrangements, the availability of plant foods is usually assured. Among these people the initiation of young men emphasized social, sexual and subsistence obligations and, thereby, framed future expectations of convention and conformity (Sørum n.d.). In secular contexts too young Bedamuni males are sometimes collectively rebuked as irresponsible and encouraged to accept the authority of seniors (Minnegal and Dwyer 1998:387-88). This is not the case among Kubo.

Both fishing communities have characteristics that contribute to a sense of security of supply. In the case of seiners this is achieved via cooperative relations that are paralleled among Kubo by an ethos of sharing that acts to buffer local shortfalls in the availability of resources. In the case of scallopers this is achieved via the capacity to switch to alternate fisheries when scallops are unavailable and is paralleled among Kubo by reliance upon diversified modes of production to accommodate booms and busts in key resources. Seiners, however, are unlike both Kubo and scallopers but are like Bedamuni in that group cohesion contributes to a sense of security of tenure with respect to access to key resources. Further, among scallopers the capacity to switch between modes of production is combined with an ethos that valorizes short-term maximization of individual returns and, in this latter characteristic, they conform more closely to the risk-prone features of Bedamuni society than to the risk-averse features of Kubo. Finally, to stretch the analogies, we might speculate that while 'initiation' into the Danish seine fishing is grounded in participating as a fisher - on a boat and at sea where the predominant experience is of the praxis of fishing - 'initiation' into the scallop fishery is additionally grounded in learning one's place as a junior in a convention-bound, status-conscious and past-oriented community of actors.

In our earlier report on responses to drought by Kubo and Bedamuni we argued that prevailing expressions of ethos and sociality were primary in patterning those responses (Minnegal and Dwyer 2000a). Our opinion on this matter has not changed. However, in summarizing key aspects of ethos and sociality in each of those societies we wrote as though all features - expressions of autonomy, sharing, tenure, etc. - came as a 'package deal' and, in each society, were necessarily functionally linked. In our analysis of key aspects of sociality among seiners and scallopers we now identify some characteristics of each community that are Kubo-like and others that are Bedamuni-like. That is, as noted above, with reference to our depiction of forms of social complexity on axes of 'involvement of parts' and 'individuation of form' (Fig. 1A), characteristics of the two fishing communities cross-cut those of the two Papua New Guinean communities. To this extent, therefore, any implication of functional necessity with respect to the Papua New Guinea cases should be regarded as suspect.

Again, in our earlier comparison of Kubo and Bedamuni we were impressed by the fact that complexity ranked higher in the latter system on both dimensions. In comparing seiners with scallopers we do not judge one system to be more complex than the other but, rather, conclude that, as they developed through the past 50 and 20 years respectively, they placed different emphases upon the two dimensions of complexity, with the seiner community ultimately emerging as the more clearly individuated and, hence, Bedamuni-like despite the fact that the internal dynamics of that individuated form are, in several respects, Kubo-like. We have suggested that systems in which complexity is strongly expressed in terms of individuation of form may be inherently vulnerable to collapse (Minnegal and Dwyer 1998:395). Subsequently we implicated these sorts of features of the Bedamuni system as contributing to their experience of the 1997 drought as being particularly severe (Minnegal 
and Dwyer 2000a:521). On analogy with Bedamuni and Kubo, we now speculate that faced with a major collapse in the availability of fish $^{7}$, and as a consequence of the cohesion that currently contributes to stability, the seiner community at Lakes Entrance would be more vulnerable than the scalloper community. Current organizational structures within the latter community which emphasize survival through diversification would place that community - or at least most members of that community - in good stead in the event of a resource catastrophe.

\section{Causality, Responsibility and Myths of Nature}

The role of perturbation, particularly climatic events, in shaping human history has received attention from many authors including archaeologists, paleoecologists, and historical ecologists (e.g. Crumley 1994; Diamond 2005; Haberle 2000; Hecht 1999; Hoffman 1999b; Moseley 2002; Sheets 1999). We ourselves have speculated that perturbations such as catastrophic droughts could have been implicated in either or both the origin and demise of systems like that of Bedamuni (Dwyer and Minnegal 2000:267). Haberle and Chepstow Lusty (2000) argued that a shift to warmer, wetter and more stable climate influenced the emergence of agricultural systems in Highland New Guinea after about 9000 years BP. Similarly, in a review of some other studies, they suggested an association between prolonged droughts and the decline of Mayan culture, between a phase of low ENSO activity (and hence favorable climate) and the resource-demanding period of statue-building on Easter Island, and between a period of intense ENSO activity (together with frequent volcanic eruptions) and the ultimate collapse of the Easter Island society. These sorts of case histories are, however, coarsegrained. They may illustrate a role for environmental perturbation in the rise or fall of particular societies but cannot identify more subtle details of shifts in sociality and complexity. Our interest here is with those details.

To implicate past perturbations as contributing to expressions of current social forms is complicated, in the present study, by the facts that, on the one hand, it was existing differences between Kubo and Bedamuni that informed their responses to a common perturbation and, on the other, the existing social configurations of seiners and scallopers appear to have emerged as different responses to structurally similar perturbations. Certainly there can be no simple relationship between environmental perturbation and social transformation. To sustain a link requires that we identify other factors that may influence the trajectory of change. That link, we suggest, may connect with ways in which the people themselves understand the causal bases of encounters with events beyond the range of the normal.

In the Bedamuni case we have argued that mythological understandings contributed to the understandings that they themselves, through inappropriate behavior, may have contributed to the events that befell them and, through appropriate behavior, to their ability to survive those events (Dwyer and Minnegal 2000). In the Danish seine fishery, though in a secular and not a mythological frame, people similarly attributed collapse in the fishery to their own behavior; they had caught more fish than the market could absorb. Self-attribution - self-blame - may provide a frame within which people may also actively assume responsibility for a future in which similar mistakes and outcomes appear to be less likely (cf. Douglas 1992). ${ }^{8}$ Where the environment is perceived as holding communities accountable for the actions of their members, we might expect the emergence of social mechanisms that define and defend the bounds of appropriate behavior and the groups of those who adhere to it, mechanisms of evaluation and integration that contribute to the individuation of form and a concomitant security of tenure.

Elsewhere we have described Kubo as understanding environment as yielding necessary resources - not always the same resources - without a requirement that they themselves reciprocate

7. The potential for a collapse in availability of fish to seiners lies in emerging competition for stocks and for markets from technologically advanced and highly capitalized otter-board trawlers. In recent years, the latter boats, which usually fished more distance waters, in response to declining stocks of their previous targets and emerging competition from autolongliners have been tempted by recent increases in market price of flathead, which were formerly regarded as a low quality fish.

8. Issues of blame and responsibility with respect to interpretations of, and responses to, major perturbations are touched upon by several authors in the edited collection Catastrophe and Culture (Hoffman and Oliver-Smith 2002). 
(Dwyer and Minnegal 1998). Borrowing from Bird-David (1990) we wrote of a 'giving environment.' Such an understanding offers a conceptual prop for our assertion that, ecologically, Kubo pattern their lives around an expectation of security of supply. But, equally, such an understanding means that Kubo are unlikely to reflect on the possibility that they themselves may have been responsible for resource failures of any magnitude. The causal bases of such failures are understood to lie elsewhere. ${ }^{9}$ And, in a general sense, much the same may be said of the way in which scallopers understood and continue to understand the fishery collapse of the 1980s. They were not responsible. Irrespective of whether they acknowledge a contribution from over-fishing they seek primary causes elsewhere - failures of management, scientific ignorance - and point to the fact that, before the extraordinary boom and ultimate collapse, they operated within a system of internal regulation in which those who were able to participate did well. Thus, neither Kubo nor scallopers have good reasons to attribute threats to resources to their own actions. Nor, therefore, have they a substantive motive for transforming social relations to secure those resources. In this regard their own actions are irrelevant and a more appropriate response will be to pattern life in such a way that they are not critically reliant on a specialized mode of production.

These reflections on the contribution of a sense of agency, a sense of control over and responsibility towards environment, resonate with some earlier discussions of the different ways in which people - including ecologists trained in western scientific traditions - may conceptualize 'nature' and understand both the risks entailed in their use and management of environment and the responsibilities they incur as a result (Douglas 1992:262; Holling 1979; Milton 1996:32,92-93). Thompson et al. (1990:25-38), who follow Holling in terming these different conceptualizations "myths" of nature, provide a useful analysis of ways in which particular myths may map onto different "ways of life" (Fig. 1B), serving to prop or rationalize distinct patterns of action. Here we borrow from their analysis to draw attention to a particular problem that is inherent in the models of Douglas and Thompson et al., and in our own. That problem, as we elaborate below, concerns the awkward notions of 'autonomy' and 'individualism'.

The myth of "Nature Ephemeral" understands nature as vulnerable and unforgiving, and requires effective sanctions to prevent deleterious outcomes arising as a consequence of the use of resources. It "encourages timorous forbearance" and an ethos of restraint on exploitation (1990:27). "Nature Perverse/Tolerant" understands nature to be bountiful within limits. It requires regulation against unusual circumstances and control over excessively exuberant behavior. Under both these myths, therefore, people may understand themselves as holding some responsibility for events that befall them. The first myth fits our account of the seiner community; the second fits our account of Bedamuni.

Thompson et al. depict the myth of "Nature Capricious" as an understanding of the world as being essentially random, a world in which life is a lottery, where luck rather than learning and skill brings resources your way. It is a myth that reconciles those who experience the world as beyond their control and whose attitudes are, in this sense, fatalistic. This myth, then, fits our account of the scalloper community which, we have argued, attributes the causes of undesirable events and outcomes to external, and essentially unpredictable and unmanageable, forces. "Nature Benign" understands nature as "wonderfully forgiving", as justifying trial and error, and as guaranteeing that skill will be rewarded by favorable outcomes. It "encourages bold experimentation in the face of uncertainty" (1990:27). Again, therefore, as with "Nature Capricious," adherents to this understanding have no basis from which to conclude that they themselves were responsible for resource failures. To some extent we can accommodate Kubo here. ${ }^{10}$ Yet Thompson et al. depict adherents to this fourth myth as

9. Carrier (1982) has argued that Ponam (Manus, Papua New Guinea) understandings of environment attribute agency to individual species and the cause of change in species abundance to God's will rather than to the actions of people. "Under the Ponam view, human effort cannot produce outcomes of a preservationist sort because humans were not implicated as cause in the disruptive events” (Dwyer 1994:92). Paolisso (2002:232), reports, similarly, that Chesapeake Bay crab fishers consider that God is managing blue crabs and that "human efforts to manage nature are not only redundant but lead to results that are not productive and beneficial to the fishery."

10. Kubo are not 'fatalists', in Thompson et al.'s sense. Fatalism is a slippery concept. People who consider that they are not causally implicated in, or lack responsibility for, particular changes in their local environment may, or may not, hold the view that they have the capacity to adjust to and, hence, manage those changes. It is only those who consider that they lack this capacity - irrespective of the objective status of their opinion - that we refer to as 
'individualists' (Fig. 1B), as advocates of the free market whose attitudes to the management of resources are laissez faire (see also Douglas 1982:192-94). These characteristics do not describe Kubo, and the seeming discrepancy directs attention to a complication that is recognized, but not resolved, by both Thompson et al. and Douglas in their respective formulations.

Thompson et al. identify a fifth myth of nature - "Nature Resilient” or the "Hermit's Myth" that subsumes but stands outside the other four. To Thompson et al. the hermit is autonomous, withdrawn, living as a recluse in a non-coercive world. On the one hand, the hermit is presented as the embodiment of 'autonomy' which, in their diagrammatic representation, is located at the intersection of grid and group axes; on the other, however, they argue that the hermit has no place in the social field defined by those axes. Douglas, too, has written of the hermit (1982:231-38). To paraphrase her understandings, the hermit "rejects competition," "refuses to control others," and occupies "an undemanding social environment" where "no contrast is sharply drawn between nature and culture". He bears no animosity to "outsiders or foreign ways," finds that "travel is even a good way of keeping withdrawn," "tolerates mixtures happily," and "does not treat any boundaries as sacred."

Douglas' descriptions of the hermit resonate strongly with our understanding of Kubo. They are non-competitive, do not polarize nature and culture, welcome outsiders as potential members of the group, resolve disputes by relocation, express use rights through action and not through commitment to fixed boundaries, and move easily between different modes of subsistence (Dwyer 1996; Dwyer and Minnegal 1998; Minnegal and Dwyer 1999, 2000b). These attributes of a community are indicative of both low involvement of parts and low individuation of form - of low grid, low group - and, hence, that is where we locate Kubo in our classification of social systems (Fig. 2). ${ }^{11}$ But what emerges here is, first, that the myth of nature which sustains Kubo is a hybrid of "Nature Benign" and "Nature Resilient" as these are described by Thompson et al. - it is 'the giving environment' - and, secondly, that social systems of very different kinds may be characterized as showing low involvement of parts and low individuation of form. The key difference concerns the embeddedness of participants within the system, the degree to which their engagement is with relational or anonymous others. This difference, we consider, has been conflated in earlier models. In the next section of this paper we enlarge upon that difference and turn our attention to the sorts of social systems that prevailed at the time of, and before, the fisheries collapses experienced by seiners and scallopers.

\section{Autonomy, Individualism and History}

We have described Kubo as committed to an ethos of autonomy that is expressed at the level of individual or family as the freedom to move, the freedom to switch between modes of appropriating resources, and the freedom not to conform (Dwyer and Minnegal 1998; cf. Bird-David 1992). But that autonomy of action is constrained by a communal responsibility to give, a commitment to generalized reciprocity toward others who are kin, close associates or even outsiders. Autonomy, for Kubo, is always relational. Kubo are embedded in, and indeed derive their sense of self from, relationships with particular others.

Kubo, however, are not 'individualistic' in the sense that Douglas and Thompson et al. write of such people. The individualist is "always his own man, blunt and forthright, given to measuring success in material terms, and much impressed by the free operation of the market as a mechanism for increasing wealth and welfare” (Thompson et al. 1990:7). Certainly, autonomy of action is valued by

'fatalists'. Further, as in the case of scallopers, an attitude of fatalism held in relation to particular kinds of events will not necessarily be generalized to all events.

11. Douglas locates the hermit off the "map of social control" at the low extreme of grid but the high extreme of group where he may yet present "a view of what human nature might be like" (1982:204,232-34). Our diagnosis appears different in locating this ideal type at the origin point of the axes of 'involvement' and 'individuation,' at the extreme of both low grid and low group. Douglas, however, treats each hermit in isolation where we prefer to imagine all hermits as sharing an interest in common and, hence, in the abstract, as a 'community' of actors. Indeed, as the ties that bind, and distinguish, a set of actors are progressively weakened so the system comprising those actors must take progressively lower values on axes of both involvement of parts and individuation of form until ultimately we arrive at hermits. But at the imaginable, though impossible, extremes the individual actor is a unitary, unengaged, being and the infinitesimal and the infinite, as icons of wholeness or oneness (Mimica 1988:107,138), implode. This, in essence, is a philosophical complication that renders Douglas' depiction of the stand-alone hermit different to ours of a class of hermits. 
the individualist but now there is no sense of communal responsibility, for individualists are disembedded from relationships and treat all others as anonymous. The metaphors Douglas and Thompson et al. use in reference to communities of individualists are 'free market' and 'laissez faire.'

Both Kubo and individualists, we assert, are characterized by low involvement of parts and low individuation of form. In the frame of Thompson et al.'s schema they are located as low grid, low group. It might be argued, of course, that with reference to embeddedness - to relations with others and to the gift and market economies within which they are, respectively, located - that Kubo exhibit greater involvement of parts than do individualists. But this is countered, in the first instance, by the competitive tendencies of individualists and, as well, by the likelihood that among these people inequalities are strongly expressed in the domain of gender relations. It is countered also by the fact that in the experience of people such as Kubo all contactable others are essentially like themselves, while in the experience of individualists many contactable others are unlike themselves. With reference to these attributes, individualists would seem to score higher than Kubo on both dimensions of social complexity. The distinction we are making might be expressed crudely as that between 'pre-modern' and 'modern' societies or, better, between societies that prioritize, respectively, relational and categorical epistemologies (Dwyer and Minnegal 2006). It is this distinction, of course, that intrudes a complication of scale into the schema we have offered as a descriptor of social complexity (Fig. 1). Our two dimensional schema is incapable of simultaneously assigning values to the characteristics of communities that differ with respect to predominate epistemologies. A schema that included an appropriate third axis would allow placement of both Kubo and individualists relatively close to the origin point for both 'involvement' and 'individuation' while placing them far apart with respect to epistemological orientation.

Now, however, our focus is with individualists and change. We have argued that the immediate preconditions to collapse in both the Danish seine and scallop fisheries were "perceptions of great resource abundance, very rapid expansion of the fleet and minimal intrinsic or extrinsic constraints on fishing effort or catch.” In each case, this was a period when laissez faire management prevailed and fishers acted independently and without constraint. They were, in effect, communities of "frontier individualists” to use Douglas' apt diagnosis (1982:194). She quoted William Faulkner's description of the people who eventually established the town of Jefferson in the United States: "these were frontier, pioneer times, when personal liberty and freedom were almost a physical condition like fire or flood, and no community was going to interfere with anyone's morals so long as the amoralist practiced elsewhere” (W. Faulkner’s Requiem for a Nun, quoted in Douglas 1982:194).

In both fisheries, this phase in their history at Lakes Entrance lasted little more than five years. Frontier individualism, Douglas argues, is inherently unstable. It "generates internal pressures for change ... has no control on information" and "any forces making for equilibrium are continually subject to disturbance" (1982:193). A society of frontier individualists is "always under threat of developing towards monopoly ... or moving into protective cartels and price rings” (1982:194). She might well have written that frontier individualism sets the scene for a tragedy of the commons: open access, self-interest, rapid population growth, rates of resource use that exceed replacement rate of those resources (i.e. overpopulation), and the only solution a change in both social form and concomitant moral values (Hardin 1968). This tragedy, then, was the experience of both communities of fishers and, in each case, as described above, their solutions were to transform social relations, to shift in the direction of cooperative closure in the case of seiners and the direction of diversified modes of production and hierarchical organization in the case of scallopers. The fragility of frontier individualism has no equivalent among Kubo for the simple reason that their relational epistemology is located in a context where the linkage between population density and resource availability does not jeopardize either reproduction of Kubo life-ways or replenishment of the resources upon which they depend.

If frontier individualism is inherently unstable, and characterized the two fishing communities in the period immediately preceding collapse, then it is incumbent upon us to consider the social forms that were precursors to those individualistic phases. In the case of scallopers our information is satisfactory; in the case of seiners we have few clues. The former operated from Lakes Entrance for a decade before the fishery became open access. The latter arrived at Lakes Entrance from elsewhere and as frontier individualists.

Through much of the 1970s the scallop community at Lakes Entrance was internally (though despotically) regulated and characterized by cohesion, limits on membership, hierarchical organization, a tendency toward entrepreneurship, and some control over the market. These characteristics position 
that community as having been higher on axes of both involvement of parts and individuation of form than was the case immediately prior to collapse or is the case now. As noted above these characteristics were ultimately dissolved not by collapse of the fishery but by legal and government intervention that effectively restructured the fishery as open access while, at the same time, providing opportunities in the form of newly discovered beds of scallops for all fishers - previous participants and new entrants to perform as unconstrained maximizers. In an important sense, therefore, intervention by outsiders destroyed the preexisting social cohesion of the scallop community and subsequent events (i.e. the collapse of stock in the mid-1980s) led to fragmentation of membership and diversification of productive effort. If the history of the Lake Entrance scallop community is considered from the time of origin in the late 1960s then the combined effect of outside intervention and collapse of stock has been to promote a shift from a more to a less individuated social system.

Our understanding of the earlier form of the seiner community, at the time when it was located in New South Wales, is much less secure. It seems that entrepreneurs played a role in the organization of that community (see Note 4) and to this extent, at least, we surmise that seiners were less individualistic than they became and less cooperative than they are now. These speculations concerning change in both communities of fishers are summarized on Figure 5.

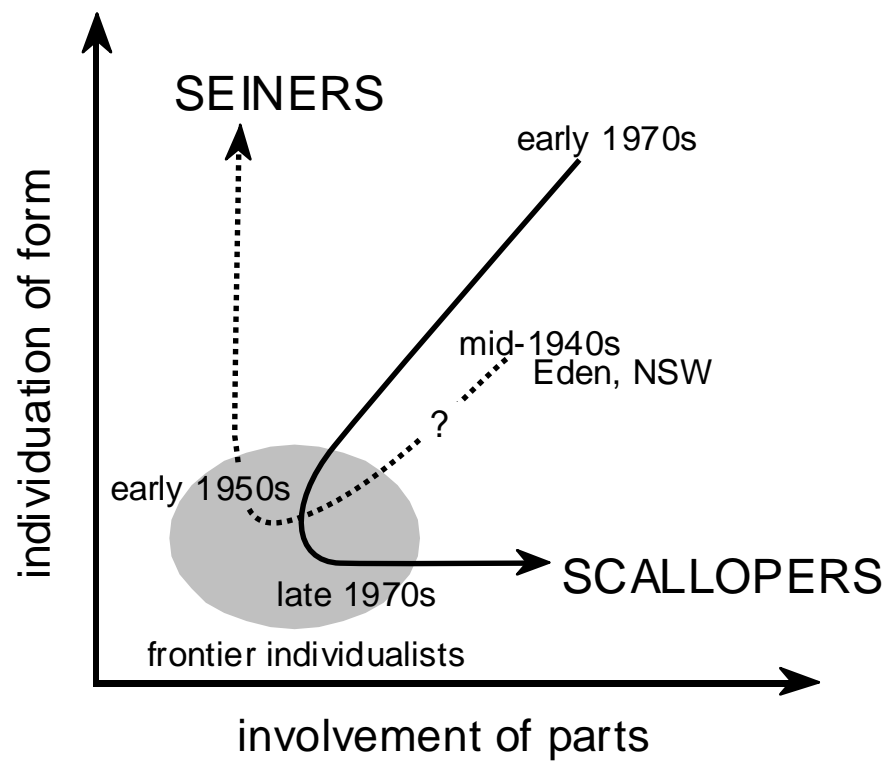

Fig. 5. Directions of change in ethos and sociality of seiner and scalloper communities.

Hoffman (1999b) has described social changes that followed a 1956 earthquake on the Greek island of Thera. Few deaths occurred but "every one of the island's twelve villages was largely destroyed, and almost the entire population, some fourteen thousand, was displaced as their homes crumbled about them" (Hoffman 1999b:315). Departure, and failure to return, of the least and most wealthy people from the island reduced inequalities among those who remained and changes to marriage patterns and living arrangements, with less emphasis on endogamy, matrilineality and sorority, reduced the 'boundedness' of particular communities. The changes described may thus be generalized as reflecting decreases in both the involvement of parts and the individuation of form and, as emphasized by Hoffman, a gradual shift toward individualism. The last may be understood as predisposing the inhabitants of Thera to eventually - nearly 20 years later - exploit economic opportunities offered by tourism and, in turn, encourage the return of former residents and their now adult children. The life experiences and values of the returnees were urban rather than rural-based with the ultimate outcome that "resident villagers let ravel the thread of custom, the patois of continuity, of habit, adage, and dirge” (Hoffman 1999:318). In broad outline, the directions of change on Thera are 
comparable to those of the early changes we have depicted on Figure 5 for seiners and scallopers. And, though we would not suggest that the more recent inhabitants of Thera might be judged as frontier individualists, their progressive adherence to, and exploitation of, values and economic opportunities that are a concomitant of capitalistic systems, was itself analogous to changes we report in the fishing communities.

\section{Concluding Remarks}

Environmental perturbations may be experienced in different ways by different communities and, in consequence, have quite different short- or long-term social consequences for those communities. We have argued that preexisting social arrangements and prevailing ethos will both constrain and condition responses to perturbation. This will be the case irrespective of the ultimate source of perturbation - a 'natural' imposition such as that experienced by Kubo and Bedamuni, an 'economic' imposition such as that experienced by seiners, or a 'managerial' imposition such as that experienced by scallopers. We have argued also that the trajectory of social transformation will not be directly influenced by the nature or the extent of the perturbation per se. Rather, it will be strongly influenced by people's prior understandings of their relations with environment and with each other, with their understandings of the extent to which they themselves were causal agents and, hence, their understandings of the extent to which they held some responsibility for the events that befell them and might thus act to ameliorate the likelihood or the effects of similar perturbations in the future.

The argument we have presented is admittedly limited in that, for analytical purposes, we have treated the communities we discuss as though they stand more-or-less alone. Where predominant perturbations arise in a globalized world of politico-economic intrusion a diversity of stakeholders may confront one another with their distinct desires and agendas. In these circumstances analysts commonly focus on the relationships of power that separate those stakeholders and seem to drive transformations that occur. But the ways in which power relations play out in mixed assemblies of people will themselves be informed by the attitudes toward 'nature' held by different interest groups (Meltzoff et al. 2005). An anthropological perspective on these issues recognizes that responses to perturbation will be always underlain by what are, essentially, the cosmological certainties that inform people's lives. The politics of political ecology is often, as Roepstorff (2003) stressed, the surface representation of clashing cosmologies.

\section{References Cited}

Allen, B. J.

"El Niño and the Drought in Papua New Guinea.” The Asia-Pacific Magazine 9/10 (1998):3942.

Allen, B. J. and R. M, Bourke

Report of an Assessment of the Impacts of Frost and Drought in Papua New Guinea. Australian Agency for International Development, 1997.

Allen, B. J., R. M. Bourke with J. Burton, S. Flew, B. Gaupu, S. Heia, P. Igua, S. Ivahupa, M. Kanau,

P. Kokoa, S. Lillicrap, G. Ling, M. Lowe, R. Lutulele, A. Nongkas, M. Poienou, J. Risimer, R. Sheldon, J. Sowei, K. Ukegawa, N. Willson, D. Wissink and M. Woruba

Report of an Assessment of the Impacts of Frost and Drought in Papua New Guinea - Phase 2. Papua New Guinea Department of Provincial and Local Government Affairs with Australian Agency for International Development, 1998.

Amit, V. (Editor)

Realizing Community: Concepts, Social Relationships and Sentiments. London: Routledge, 2003.

Baelde, P.

"Fisher's Descriptions of Changes in Fishing Gear and Fishing Practices in the Australian South East Ttrawl fishery.” Marine and Freshwater Research 52 (2001):411-17.

Bennett, R., J. Mure and G. Mure

The Photographer, the Cook and the Fisherman: Real Stories of Tasmanian Fishing. Hobart, Tasmania: Richard Bennett, Jill and George Mure, 2002.

Biersack, A

"Introduction: From the 'New Ecology' to the New Ecologies.” American Anthropologist 10 (1999):5-18. 
Bird-David, N.

"The Giving Environment: Another Perspective on the Economic System of Gatherer-hunters." Current Anthropology 31 (1990):189-96.

— "Beyond 'the Hunting and Gathering Mode of Subsistence': Culture-sensitive Observations on the Nayaka and other Modern Hunter-gatherers.” Man (N.S.) 27 (1992):19-44.

Bourke, R. M.

"Impact of the 1997 drought and frosts in Papua New Guinea". In El Niño: History and Crisis: Studies from the Asia-Pacific Region edited by R. H. Grove and J. Chappell, 149-70. Cambridge: White Horse Press, 2000.

Brosius, $\mathrm{P}$.

"Comment on 'After Nature: Steps to an Antiessentialist Political Ecology’” by A. Escobar. Button, G. V. Current Anthropology 40 (1999):16-17.

"The Negation of Disaster: The Media Response to Oil Spills in Great Britain.” In The Angry Earth: Disaster in Anthropological Perspective edited by A. Oliver-Smith and S. M. Hoffman, 112-32. New York: Routledge, 1999.

Caplan, P. (Editor)

Risk Revisited. Pluto Press, London: Pluto Press, 2000.

Carrier, J. G.

"Conservation and Conceptions of the Environment: A Manus Case Study. In Traditional Conservation in Papua New Guinea: Implications for Today” edited by L. Morauta, J. Pernetta, and W. Heaney, 39-43. Boroko, Papua New Guinea: Institute of Applied Social and Economic Research, 1982.

Caton, A. (Editor)

Fisheries Status Reports 2000-2001. Canberra: Bureau of Rural Sciences, Australian Commonwealth Government, 2002.

Caton, A. and K. McLoughlin (Editors)

Fisheries Status Reports 1999. Canberra: Bureau of Rural Sciences, Australian Commonwealth Government, 2000.

Connell, J. H.

“Diversity in Tropical Rain Forests and Coral Reefs.” Science 199 (1978):1302-10.

Connor, R. and D. Alden

"Indicators of the Effectiveness of Quota Markets: The South East Trawl Fishery of Australia." Marine and Freshwater Research 52 (2001):387-97.

De Garine, I. and G. A. Harrison (Editors) Coping with Uncertainty in Food Supply. Oxford: Clarendon Press, 1988.

Diamond. J. Collapse: How Societies Choose to Fail or Succeed. New York: Viking, 2005.

Douglas, $\mathrm{M}$.

Natural Symbols. Middlesex: Penguin Books, 1970.

- In the Active Voice. London: Routledge and Kegan Paul, 1982.

Dwyer, P. D.

Risk and Blame: Essays in Cultural Theory. London: Routledge, 1992.

"Modern Conservation and Indigenous Peoples: In Search of Wisdom.” Pacific Conservation Biology 1 (1994):91-7.

"The Invention of Nature.” In Redefining Nature: Ecology, Culture and Domestication." Pages 157-186 in R. Ellen and K. Fukui, editors, 157-86. Oxford: Berg, 1996.

Dwyer, P. D., R. Just, and M. Minnegal.

"A Sea of Small Names: Fishers and their Boats in Victoria, Australia." Anthropological Forum 13 (2003):5-26.

Dwyer, P. D. and M. Minnegal

"Waiting for Company: Ethos and Environment among Kubo of Papua New Guinea." The Journal of the Royal Anthropological Institute 4 (N.S.) (1998):23-42.

"The Transformation of Use Rights: A Comparison of Two Papua New Guinean Societies.” Journal of Anthropological Research 55 (1999):361-383. 
"El Niño, Y2K and the Short Fat Lady: Drought and Agency in a Lowland Papua New Guinean Community.” Journal of the Polynesian Society 109 (2000):251-272.

"The Good, the Bad and the Ugly: Risk, Uncertainty and Decision-making by Victorian Fishers.” Journal of Political Ecology 13 (2006):1-23.

Dwyer, P. D., M. Minnegal, and V. Woodyard

"Konai, Febi and Kubo: The Northwest Corner of the Bosavi Language Family.” Canberra Anthropology 16 (1993):1-14.

Escobar, A.

"After Nature: Steps to an Antiessentialist Political Ecology.” Current Anthropology 40 (1999):1-29.

Gezon, L.L.

"Of Shrimps and Spirit Possession: Towards a Political Ecology of Resource Management in Northern Madagascar.” American Anthropologist 10 (1999):58-67.

Grove, R. H. and J. Chappell (Editors)

El Niño: History and Crisis: Studies from the Asia-Pacific Region. Cambridge: White Horse Press, 2000

Haberle, S. G.

"Vegetation Response to Climate Variability: A Palaeoecological Perspective on the ENSO Phenomenon.” In El Niño: History and Crisis: Studies from the Asia-Pacific Region edited by R. H. Grove and J. Chappell, 66-78. Cambridge: White Horse Press, 2000.

Haberle, S. G. and A. Chepstow Lusty

"Can Climate Influence Cultural Development? A View through Time.” Environment and

Hardin, G. History 6 (2000):349-69.

Hecht, J.

"The Tragedy of the Commons.” Science 162 (1968):1243-48.

"Born in a Storm.” New Scientist 162 (1999):38-41.

Hester, R. E. and R. M. Harrison (Editors)

Global Environmental Change. London: Royal Society of Chemistry, 2002.

Hewitt, K. (Ed.)

Interpretations of Calamity: From the Viewpoint of Human Ecology. Boston: Allen \& Unwin Inc., 1983

Hoffman, S. M.

"The Worst of Times, the Best of Times: Towards a Model of Cultural Response to Disaster." In The Angry Earth: Disaster in Anthropological Perspective edited by A. Oliver-Smith and S. M. Hoffman, 134-55. New York: Routledge, 1999a.

“After Atlas Shrugs: Cultural Change or Persistence after a Disaster.” In The Angry Earth: Disaster in Anthropological Perspective edited by A. Oliver-Smith and S. M. Hoffman, 302-25. New York: Routledge, 1999b.

Hoffman, S. M. and A. Oliver-Smith (Editors)

Catastrophe and Culture: The Anthropology of Disaster. Sante Fe: School of American Research Press, 2002.

Holling, C. S.

"Myths of Ecological Stability: Resilience and the Problem of Failure." In Studies in Crisis Management edited by G. Smart and W. Standbury, 93-107. Butterworth, Montreal: Butterworth, 1979.

Ingold, T.

The Perception of the Environment: Essays in Livelihood, Dwelling and Skill. London: Routledge, 2000

Kirsch, S.

“Environmental Disaster, 'Culture Loss,' and the Law.” Current Anthropology 42 (2001):16798.

Knauft, B. M.

"Ritual Form and Permutation in New Guinea: Implications of Symbolic Process for Sociopolitical Evolution.” American Ethnologist 12 (1985): 321-340. 
Laksono, P. M.

"Perception of Volcanic Hazards: Villagers versus Government Officials in Central Java.” In The Real and Imagined Role of Culture in Development: Case Studies from Indonesia edited by M. R. Dove, 183-200. Honolulu: University of Hawaii Press, 1988.

Langer, S. K.

Mind: An Essay on Human Feeling, Vol. I. London: John Hopkins University Press, 1967.

Lee, T. and J. Ellis

Casting the Net: Early Fishing Families of the Gippsland Coast. An Oral History Project of the Lakes Entrance Family History Resource Centre. Bairnsdale, Australia: James Yeates and Sons Printing, 2003.

McCabe, J. T.

"Impact of and Response to Drought among Turkana Pastoralists.” In Catastrophe and Culture: The Anthropology of Disaster edited by S. M. Hoffman and A. Oliver-Smith, 213-36. Sante Fe: School of American Research Press, 2002.

Mead, $\mathrm{T}$.

Killers of Eden: The Killer Whales of Twofold Bay. Sydney: Dolphin Books, 2002 [19611991].2002.

Meltzoff, S. K., M. Lemons, L. Asfour, G. Guardia-Montoya and R. Gonzales Sustaining El Niño-induced scallop booms with aquaculture: Livelihood transitions of artisanal fishing people in the Paracas National Reserve, Peru. Culture and Agriculture 27 (2005):1-15.

Milton, K.

Environmentalism and Cultural Theory: Exploring the Role of Anthropology in Environmental Mimica, J. Discourse. London: Routledge, 1996.

Intimations of Infinity: The Mythopoeia of the Iqwaye Counting System and Number. Berg, Oxford: Berg, 1988.

Minnegal, M. and P. D. Dwyer

"Intensification and Social Complexity in the Interior Lowlands of Papua New Guinea: A Comparison of Bedamuni and Kubo.” Journal of Anthropological Archaeology 17 (1998):375400.

"Re-reading Relationships: Changing Constructions of Identity among Kubo of Papua New Guinea.” Ethnology 38 (199):59-80.

"Responses to a Drought in the Interior Lowlands of Papua New Guinea: A Comparison of Bedamuni and Kubo-Konai.” Human Ecology 28 (2000a):493-526.

"A Sense of Community: Sedentary Nomads of the Interior Lowlands of Papua New Guinea.” People and Culture in Oceania 16 (2000b):43-65.

"Intensification, Complexity and Evolution: Insights from the Strickland-Bosavi Region." Asia Pacific Viewpoint 42 (2001):269-85.

Minnegal, M., T. J. King, R. Just, and P. D. Dwyer

"Deep Identity, Shallow Time: Sustaining a Future in Victorian Fishing Communities.” The Australian Journal of Anthropology 14 (2003):53-71.

Moseley, M. E.

"Modeling Protracted Drought, Collateral Natural Disaster, and Human Responses in the Andes.” In Catastrophe and Culture: The Anthropology of Disaster edited by S. M. Hoffman and A. Oliver-Smith, 187-212. Sante Fe: School of American Research Press, 2002.

Oliver-Smith, A.

"Peru's Five-hundred-year Earthquake: Vulnerability in Historical Context." In The Angry Earth: Disaster in Anthropological Perspective edited by A. Oliver-Smith and S. M. Hoffman, 74-88. New York: Routledge, 1999.

Oliver-Smith, A. and S. M. Hoffman (Editors)

The Angry Earth: Disaster in Anthropological Perspective. Routledge, New York: Routledge, 1999.

Paine, R.

"Danger and the No-risk Thesis." In Catastrophe and Culture: The Anthropology of Disaster edited by S. M. Hoffman and A. Oliver-Smith, 67-89. Sante Fe: School of American Research Press, 2002. 
Peet, R. and M. Watts (editors)

Liberation Ecologies: Environment, Development, Social Movements. New York: Routledge, 2004.

Phillips, G., L. Kriwoken, and P. Hay

"Private Property and Public Interest in Fisheries Management: The Tasmanian Rock Lobster

Quesada, C. Fishery.” Marine Policy 26 (2002):459-469.

"Men Facing Earthquakes: The Example of Rognes (Bouches-du-Rhône, France).” High Plains Applied Anthropologist 21 (2001):53-61.

Rees, M. J.

Our Final Hour. A Scientist's Warning: How Terror, Error, and Environmental Disaster Threaten Humankind's Future in this Century - on Earth and Beyond. London: Heinemann, 2003.53-61.53-61.

Robbins, P

Political Ecology: A Critical Introduction. Malden, MA: Blackwell Publishers, 2004.

Roepstorff, A.

"Clashing Cosmologies: Contrasting Knowledge in the Greenlandic Fishery.” In Imagining Nature: Practices of Cosmology and Identity edited by A. Roepstorff, N. Bubandt, and K. Kull, 117-42. Langelandgade, Denmark: Aarhus University Press, 2003.

Seafood Industry Victoria

Web Site of Seafood Industry Victoria. http://www.siv.com.au [Accessed June 16, 2003], 2003.

Shaw, R. D.

“The Bosavi Language Family.” Pacific Linguistics Series A, 70 (1986):45-76.

Sheets, P. D.

"The Effects of Explosive Volcanism on Ancient Egalitarian, Ranked, and Stratified Societies in Middle America." In The Angry Earth: Disaster in Anthropological Perspective edited by A. Oliver-Smith and S. M. Hoffman, 36-58. New York: Routledge, 1999.

Skinner, J

“The Eruption of Chances Peak, Montserrat, and the Narrative Containment of Risk.” In Risk Revisited edited by P. Caplan, 156-83. London: Pluto Press, 2000.

Sørum, A.

The Forked Branch: A Study of Meaning in Bedamini Ceremonial. Unpublished manuscript, no date.

Tasmanian DPIWE

Commercial Scallop Fishing. Tasmanian Department of Primary Industries, Water and Environment. http://www.dpiwe.tas.gov.au [Accessed July 1, 2003], 2003.

Thompson, M., R. Ellis, and A. Wildavsky

Cultural Theory. Boulder: Boulder: Westview Press, 1990.

Tilzey, R. D. J. and K. R. Rowling

"History of Australia’s South East Fishery: A Scientist's Perspective.” Marine and Freshwater Research 52 (2001):361-375.

Torrence, R. and J. Grattan (Editors)

Natural Disasters and Cultural Change. London: Routledge, 2002.

Trawick, P.

"Comedy and Tragedy in the Andean Commons.” Journal of Political Ecology 9 (2002):35-68.

Vayda, A. P. and B. B. Walters

“Against Political Ecology.” Human Ecology 27 (1999):167-79.

Whitmore, T. C.

An Introduction to Tropical Forests. Oxford: Oxford University Press, 1998.

Zaman, M. Q.

"Vulnerability, Disaster, and Survival in Bangladesh: Three Case Studies.” In The Angry Earth: Disaster in Anthropological Perspective edited by A. Oliver-Smith and S. M. Hoffman, 192212. New York: Routledge, 1999. 


\begin{abstract}
This paper proposes an anthropological approach to understanding responses to environmental perturbation, one that is aligned with the humanistic and environmentalist agendas of political ecology while seeking to develop a more generic understanding of processes that shape human action in, as well as on, the worlds that people experience. We outline a comparative model that recognizes and prioritizes the role of prevailing expressions of ethos and sociality in conditioning responses to perturbation and takes variation in those expressions as focal to analysis. The model concerns the complexity of social systems, identifying two dimensions of complexity that we label 'the involvement of parts' and 'the individuation of form'. Drawing on our own ethnographic studies of two, linguistically-defined, societies in Papua New Guinea and two, activity-defined, communities of commercial fishers in Australia we show, first, how differences in sociality and ethos may influence short-term responses to environmental perturbation and, secondly, how environmental perturbation may, in the longer term, influence the emergence of new forms of sociality and ethos. Where new forms do emerge, we argue, the trajectory of change will be strongly influenced by people's prior understandings of their relations with environment and with each other, with their understandings of the extent to which they themselves were causal agents and, hence, their understandings of the extent to which they may act to ameliorate the likelihood or the effects of similar perturbations in the future.
\end{abstract}

Keywords: environmental perturbation, social change, myths of nature, blame

\title{
Résumé
}

Cet article propose une approche anthropologique pour comprendre les réponses à la perturbation environnementale, une qui est alignée avec les ordres du jour humanistes et d'écologiste de l'écologie politique tout en cherchant à développer une comprehension plus générique des processus qui forment l'action humaine dedans, aussi bien que dessus, les mondes expérimentés. Nous décrivons un modèle comparatif qui identifie et donne la priorité au rôle des expressions régnantes d'éthos et de socialité en influençant des réponses à la perturbation. Le modèle en outre prend la variation de ces expressions comme focales à l'analyse. Il concerne la complexité des systèmes sociaux, identifiant deux dimensions de complexité que nous marquons "la participation des pièces" et "l'individuation de la forme.” Basé sur le nos études ethnographiques de deux sociétés (définies linguistiquement) dans Papouasie Nouvelle Guinée, et deux communautés (définis par activité) des pêcheurs commerciaux en Australie, nous montrons, tout d'abord, comment les différences dans la socialité et l'éthos peuvent influencer des réponses à court terme à la perturbation environnementale et, deuxièmement, comment la perturbation environnementale peut, à plus long terme, influencer l'apparition de nouvelles formes de socialité et d'éthos. Là où les nouvelles formes emergent, affirmons nous, la trajectoire du changement sera fortement influencées pour les gens par les vues antérieures de leurs relations avec l'environnement et avec l'un l'autre. D'ailleurs, elle sera influencées par les perceptions du point auquel les individus étaient les agents causals et, par conséquent, du point auquel ils peuvent agir d'améliorer la probabilité ou les effets des perturbations semblables à l'avenir.

Mots-clès: perturbation environnementale, changement social, mythes de nature, blâme

\section{Resúmen}

Este artículo propone un acercamiento antropológico que pretende entender las respuestas a la perturbación ambiental, uno que es congruente con las agendas humanísticas y ambientales de la ecología política, buscando desarrollar un entendimiento más genérico de los procesos que forman la acción humana en y sobre el mundo que las personas perciben. Subrayamos un modelo comparativo que reconoce y prioriza el rol de las existentes expresiones de sociabilidad y ethos en el condicionamiento de las respuestas a las perturbaciones y que toma en cuenta la variación en esas expresiones como foco de análisis. El modelo concierne a la complejidad de los sistemas sociales, identificando dos dimensiones de complejidad que hemos llamado 'el envolvimiento de las partes' y 'la individualización de la forma'. Como referencia tomamos nuestro propio estudio etnográfico de dos sociedades lingüísticamente definidas de Papua Nueva Guinea y dos comunidades definidas por actividad, comunidades de pescadores comerciales en Australia. Mostramos primero como las diferencias en la sociabilidad y en el ethos pueden influenciar las respuestas a corto plazo a las perturbaciones ambientales y, segundo, como las perturbaciones ambientales influencian en la emergencia de nuevas formas de sociabilidad y ethos a largo plazo. Donde aparecen estas nuevas formas, discutimos que la trayectoria del cambio será fuertemente afectada por el entendimiento a priori que las personas tengan de su medio ambiente y de las relaciones interpersonales, del grado en que ellos mismos fueron agentes causales de tales y por lo tanto del entendimiento del grado en que ellos pueden actuar para mejorar las posibilidades o los efectos de similares perturbaciones en el futuro.

Palabras clave: perturbación ambiental, cambio social, mitos de la naturaleza, culpa 